\title{
Pengembangan Modul Pratikum Berbasis Pendekatan PACE (Planing, Activities, Class discussion, Exercise) untuk Meningkatkan Motivasi Belajar siswa pada Materi Listrik Dinamis kelas IX di SMP Negeri 10 Takengon Kabupaten Aceh Tengah
}

\author{
Syukrimansyah $^{1)}$, M. Hasan ${ }^{2)}$, Rini Safitri ${ }^{3)}$ \\ ${ }^{1)}$ Program Studi Pendidikan IPA Program Pascasarjana Universitas Syiah Kuala Banda Aceh 23111 \\ ${ }^{2)}$ Program Studi Kimia FKIP Universitas Syiah Kuala Banda Aceh 23111 \\ 3) Jurusan Fisika FMIPA Universitas Syiah Kuala Banda Aceh 23111 \\ e-mail: syukriamsyah84@gmail.com
}

\begin{abstract}
This research was conducted with the title development lab module PACE approach based on dynamic electrical material. The study was conducted in SMP Negeri 10 Takengon. Mixed Methods This study uses an embedded design experimental model. ADDIE (Analysis, Design, Development, Implementation, and Evaluation). This method consists of two basic processes, which is accompanied by a quantitative research, qualitative research embedded in it, and the process based on a qualitative interpretation of research results. Quantitative research design using Pre-Experimental design The design uses one group pretest posttest design. Questionnaire to determine the motivation of students before and after using the module Pace in learning. Normality and homogeneity test results show that the data homogeneous and normal distribution. $T$ test results obtained $t$ count $>t$ table $(4.55>2.02)$ means that there is a difference in student learning outcomes after using the module Pace. In addition, students also gave a positive response to the use of PACE module, so it can be concluded that learning with PACE module can increase student motivation.
\end{abstract}

\section{Keywords: Module, PACE, Motivation.}

Abstrak. Penelitian ini dilakukan dengan judul pengembangan modul praktikum berbasis pendekatan PACE pada materi listrik dinamis. Penelitian dilakukan di SMP Negeri 10 Takengon. Penelitian ini menggunakan Mixed Methods desain embedded experimental Model. Pendekatan yang digunakan adalah model ADDIE (Analysis, Design, Development, Implementation, and Evaluation) Metode ini terdiri dari dua proses pokok, yaitu jenis penelitian kuantitatif disertai dengan penelitian kualitatif yang embedded di dalamnya, dan proses interprestasi kualitatif didasarkan pada hasil penelitian. Rancangan penelitian kuantitatif menggunakan Pre-Experimental design menggunakan rancangan The One Group Pretest Posttest Design. Angket untuk mengetahui motivasi siswa sebelum dan sesudah menggunakan modul Pace dalam pembelajaran. Hasil uji normalitas dan homogenitas menunjukkan bahwa data homogen dan berdistribusi normal. Hasil uji t diperoleh t hitung $>$ ttabel $(4,55>2,02)$ artinya terjadi perbedaan hasil belajar siswa setelah menggunakan modul Pace. Selain itu siswa juga memberikan tanggapan yang positif terhadap penggunaan modul PACE, sehingga dapat disimpulkan bahwa pembelajaran dengan menggunakan modul PACE dapat meningkatkan motivasi siswa.

Kata kunci: Modul, PACE,Motivasi.

\section{PENDAhUluaN}

Ilmu Pengetahuan Alam (IPA) berkaitan dengan cara mencari tahu tentang fenomena alam secara sistematis. Pendidikan IPA diharapkan dapat menjadi wahana bagi peserta didik untuk mempelajari diri sendiri dan sekitarnya, serta prospek pengembangan lebih lanjut dalam menerapkan keilmuan di dalam kehidupan seharihari. IPA pada hakikatnya meliputi dua hal, yaitu IPA sebagai produk dan IPA sebagai proses. IPA sebagai produk berarti terdapat fakta, hukumhukum, prinsip-prinsip dan teori-teori yang sudah diterima kebenarannya. Adapun IPA sebagai proses merupakan kegiatan yang dilakukan dan sikapsikap untuk menghasilkan produk berupa ilmu pengetahuan.

Salah satu tujuan pembelajaran IPA adalah mengembangkan kemampuan berfikir analitis induktif dan deduktif dalam menyelesaikan masalah yang berkaitan dengan peristiwa alam baik secara kualitatif maupun kuantitatif, serta dapat mengembangkan keterampilan dan sikap percaya diri. Namun, observasi di lapangan memperlihatkan kondisi yang jauh dari harapan tuntutan kurikulum, pelajaran IPA khususnya fisika merupakan 
pelajaran yang kurang digemari oleh peserta didik karena pembelajaran di kelas terkesan kaku dan penyampaian materi cenderung monoton dan statis sehingga pembelajaran IPA sangat membosankan, pembelajaran sering berlangsung searah.

Berdasarkan permasalahan tersebut, untuk merubah respon peserta didik terhadap pelajaran IPA perlu dilakukan berbagai model pendekatan pembelajaran yang melibatkan siswa secara aktif dalam proses pembelajaran dengan kata lain respons siswa terhadap pelajaran fisika posistif jika siswa terlibat langsung dalam proses pembelajaran. Respons yang positif dapat ditunjukkan oleh peserta didik dari hasil belajarnya yang telah termasuk dalam kategori berhasil baik afektif, psikomotor maupun kognitifnya. Hal ini didukung oleh pernyataan Susilo (2004) yang menyatakan bahwa adanya respons positif akan menunjang proses belajar, sikap positif akan menimbulkan minat, selanjutnya motivasi akan mudah berkembang. Sebaliknya, respons negatif akan dapat menghambat belajar, karena tidak melahirkan sikap positif dan tidak menunjang minat, serta motivasi akan sukar berkembang. Nursisto (2002) juga menyatakan bahwa salah satu bentuk pembelajaran yang dapat memotivasi peserta didik untuk belajar adalah membuat pembelajaran penuh arti. Dengan demikian dapat disimpulkan bahwa respon positif adalah perwujudan dari motivasi.

Dalam rangka meningkatkan motivasi belajar siswa tentu keterlibatan siswa dalam proses pembelajaran harus dikedepankan, seperti teori belajar yang mengutamakan aktivitas siswa untuk memperoleh sendiri pengetahuannya adalah teori belajar konstruktivisme. Teori belajar konstruktivisme mengutamakan aktivitas siswa, mengenal kegiatan laboratorium, memecahkan masalah dan mampu mendiskusikannya. Menurut Kaniawati (2010), strategi yang menonjol dalam pembelajaran konstruktivisme antara lain adalah strategi belajar kolaboratif, mengutamakan aktivitas siswa, mengenal kegiatan laboratorium, pengalaman lapangan, studi kasus, pemecahan masalah, diskusi, brainstorming, dan simulasi.

Model pembelajaran yang melibatkan siswa secara aktif adalah model pembelajaran inquiri, pembelajaran ini menekankan bahwa siswa menemukan sendiri konsep yang dipelajari, misalnya melalui kegiatan praktikum. Penelitian Furqan (2015) menyatakan bahwa pengembangan modul berbasis model pembelajaran inquiri dapat meningkatkan keterampilan proses sains dan motivasi belajar siswa pada konsep kelistrikan".
Dengan demikian berarti, praktikum merupakan kegiatan pembelajaran yang mengutamakan kerja siswa dalam memperoleh suatu konsep. Pelaksanaan praktikum dapat melibatkan semua indra siswa dalam memperoleh ilmu pengetahuan, sehingga pembelajaran dapat berkesan bagi siswa dan menjadi pembelajaran yang bermakna. Menurut Setyaningrum, dkk (2013) bahwa "kegiatan praktikum dapat melibatkan siswa secara aktif dalam mengembangkan keterampilan dan sikap ilmiah sehingga proses pembelajarannya dapat melatih aspek kognitif, aspek afektif dan aspek psikomotorik siswa".

Kegiatan praktikum memerlukan kemampuan berpikir kritis dari peserta didik. Kemampuan berpikir kritis didasari oleh proses berpikir untuk menganalisis argumen dan memunculkan wawasan terhadap tiap-tiap makna dan interprestasi (Costa dalam Liliasari, 2000). Masalah-masalah dalam kehidupan dapat dianalisis dan diselesaikan dengan ilmu pengetahuan, salah satunya adalah dengan IPA. Dengan demikian, peserta didik dapat mengembangkan kemampuan berpikir kritisnya melalui kegiatan pembelajaran praktikum. Sebagian besar guru yang sudah berpengalaman akan setuju bahwa menyampaikan informasi kepada peserta didik sangatlah penting, tetapi mengajar peserta didik bagaimana cara berpikir kritis merupakan hal yang lebih penting lagi. Di samping itu, membentuk kemampuan peserta didik yang berpikir kritis merupakan salah satu tujuan dari pendidikan karakter.

Kemampuan berpikir kritis peserta didik dipengaruhi oleh proses pembelajaran. Proses pembelajaran yang berpusat pada guru akan menghambat pembentukan peserta didik yang kritis. Kemampuan berpikir kritis tidak akan muncul begitu saja tanpa melalui proses belajar. Peranan guru sebagai motivator dapat membangun kemampuan berpikir kritis peserta didik. Guru dapat mengupayakan kemampuan berpikir kritis peserta didik meningkat melalui proses pembelajaran.

Oleh karena itu, cara efektif membentuk kemampuan berpikir kritis dalam proses pembelajaran IPA adalah dengan menggunakan pembelajaran praktikum, tentu untuk kegiatan praktikum diperlukan panduan agar praktikum yang dilaksanakan lebih terarah dan tercapai tujuan pembelajaran secara optimal. Realita sehari-hari sekolah hanya menggunakan Lembar Kerja Siswa (LKS) terbitan Erlangga, dalam LKS ini tidak tercermin langkah-langkah kongkrit dalam 
pelaksanaan praktikum, bahan ajar juga tidak ada akibatnya motivasi belajar peserta didik rendah. Observasi penulis, menunjukkan bahwa penggunaan LKS ini kurang dapat mengarahkan siswa untuk berfikir kritis dalam menganalisis permasalahan yang dihadapi siswa dalam kehidupan sehari-hari. Ditinjau dari sistematis penulisan LKS sangat berbeda dengan modul, pembuatan modul disesuaikan dengan tingkat kemampuan siswa dan situasi sarana dan prasarana sekolah serta kemahiran guru dalam melaksanakan praktikum. Hal ini juga dibenarkan oleh guru bidang studi fisika di SMP 10 Takengon menyatakan bahwa modul praktikum belum pernah ada di sekolah, sehingga kegiatan praktikum pasif.

Depdiknas (2008) menjelaskan bahwa modul merupakan bahan cetak yang dirancang untuk dapat dipelajari secara mandiri oleh peserta pembelajaran. Berdasarkan problema tersebut, maka penulis berinisiatif untuk mengembangkan modul praktikum berbasis pendekatan PACE. Suparno (2013) menyatakan bahwa "pendekatan PACE dapat meningkatkan motivasi belajar siswa, karena pendekatan PACE diawali dengan perencanaan terhadap apa yang akan dipelajari, melakukan aktivitas misalnya melakukan percobaan, mendiskusikan hasil praktikumnya dan diakhir pembelajaran diberikan latihan-latihan untuk meningkatkan wawasan dan motivasi belajar peserta didik". Dengan demikian pembelajaran yang dilakukan sebelum pendekatan PACE aktivitas siswa dapat dikategori sangat rendah dan aktivitas tersebut lebih meningkat setelah dilakukan pembelajaran dengan model pendekatan PACE, pendekatan PACE menjadikan pembelajaran lebih berpusat pada siswa, sehingga pembelajaran lebih bermakna dan hasilnya akan terpatri lebih lama. Pendekatan PACE memudahkan siswa memahami konsep fisika yang abstrak menjadi lebih nyata melalui percobaan-percobaan sederhana yang disusun secara sitematis di dalam sebuah panduan baik untuk siswa maupun untuk guru.

Pembelajaran menggunakan pendekatan PACE akan menekankan pada proses berpikir secara kritis dan analitis untuk mencari dan menemukan sendiri jawaban dari suatu permasalahan, oleh karena itu diperlukan modul pembelajaran. Hal ini sesuai dengan hasil penelitian Kamphen dkk (2003) modul dapat meningkatkan motivasi siswa terhadap pembelajaran karena modul dirancang semenarik mungkin baik dari tampilan, gambar dan sistematis sehingga siswa lebih termotivasi untuk belajar fisika. Selanjutnya
Wahyudi, (2013) menambahkan motivasi itu muncul dari dalam diri peserta didik akan tetapi kemunculannya karena adanya rangsangan atau dorongan dari luar unsur luar.

Permasalahan lain, rendahnya motivasi belajar siswa terhadap pelajaran IPA, hal ini dapat dilihat dari hasil belajarnya baik kognitif maupun psikomotornya, serta indikator motivasi seperti kesukaan, ketertarikan, keterlibatan siswa dalam proses belajar mengajar, Sardiman (2004) bahwa "Seberapa kuat motivasi yang dimiliki individu akan banyak menentukan terhadap kualitas perilaku yang ditampilkannya, baik dalam konteks belajar, bekerja maupun dalam kehidupan lainnya. Lawson, R.J (2011) kegiatan yang berfokus pada karakteristik belajar siswa meliputi motivasi, kualitas dan kemauan, faktor kontekstual juga mempengaruhi siswa seperti, niat, harapan dan prilaku dalam menentukan hasil belajar. Siswa akan berhasil dalam belajar, kalau pada dirinya sendiri ada keinginan untuk belajar, keinginan atau dorongan untuk belajar inilah yang disebut dengan motivasi. Motivasi senantiasa akan menentukan intensitas usaha belajar bagi siswa.

Berdasarkan latar belakang masalah di atas, tentu perlu dilakukan studi penelitian sebab sepengetahuan penulis permasalahan tersebut belum pernah diatasi, oleh karena itu penulis merasa penting untuk melakukan penelitian dengan judul "Pengembangan Modul Pratikum Berbasis Pendekatan PACE (Planing, Activities, Class discussion, Exercise) untuk Meningkatkan Motivasi Belajar siswa pada Materi Listrik Dinamis kelas IX di SMP Negeri 10 Takengon Kabupaten Aceh Tengah".

\section{METODE PENELITIAN}

Penelitian ini menggunakan Mixed Methods desain embedded experimental Model (Creswell\& Clark, 2007). Metode ini terdiri dari dua proses pokok, yaitu jenis penelitian kuantitatif disertai dengan penelitian kualitatif yang embedded di dalamnya, dan proses interprestasi kualitatif didasarkan pada hasil penelitian. Metode penelitian ini mengadaptasi dari desain embedded experimental. Pendekatan yang digunakan adalah model ADDIE (Analysis, Design, Development, Implementation, and Evaluation) guna mengetahui pengembangan modul fisika konsep listrik dinamis pada siswa kelas X di SMP Negeri 10 Takengon Kabupaten Aceh Tengah.

Populasi dalam penelitian ini adalah seluruh peserta didik kelas IX yang terdiri dari empat kelas. 
Yang berjumlah 92 orang. Teknik pengambilan sampel dalam penelitian ini menggunakan cluster random sampling (sampling kelompok). Sampling kelompok yaitu bentuk sampling random yang populasinya dibagi menjadi beberapa kelompok (cluster) dengan menggunakan aturan-aturan tertentu, seperti batas-batas alam dan wilayah administrasi pemerintahan. Dalam hal ini penulis hanya mengambil sampel sebanyak 25 orang yang berasal dari kelas IX.1. Pengumpulan data digunakan observasi dan angket motivasi.

\section{HASIL DAN PEMBAHASAN}

\section{Modul PACE}

Berdasarkan hasil penelitian mengenai pengembangan modul praktikum berbasis pendekatan PACE untuk meningkatkan motivasi belajar fisika siswa pada materi listrik dinamis pada siswa SMP Negeri 10 Takengon Kabupaten Aceh Tengah yang telah dilakukan, maka diperoleh hasil penelitian dan pembahasan pada masing-masing tahapan. Berdasarkan data yang diolah, pada tiap tahapan mengalami peningkatan kerah yang lebih baik. Diagram persentase perbandingan skor ratarata tiap tahap ditunjukan pada Gambar 1.

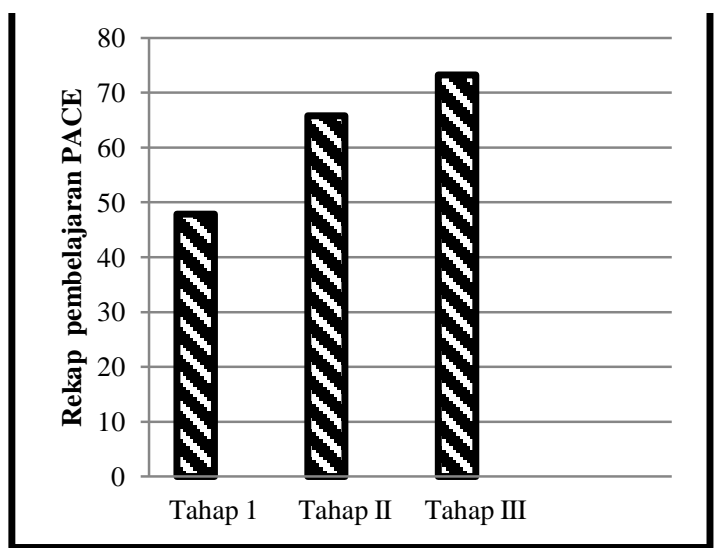

Gambar 1. Perbandingan nilai rata-rata modul PACE

\section{Deskripsi Pengembangan modul PACE \\ Terhadap Peningkatan Motivasi Siswa}

Hasil belajar dengan modul PACE yang digunakan pada materi listrik dinamis diukur dengan tes pilihan ganda. Diagram persentase perbandingan skor rata-rata pretest, posttest dan $\mathrm{N}$ gain kelas IX-1 ditunjukkan pada Gambar 2.

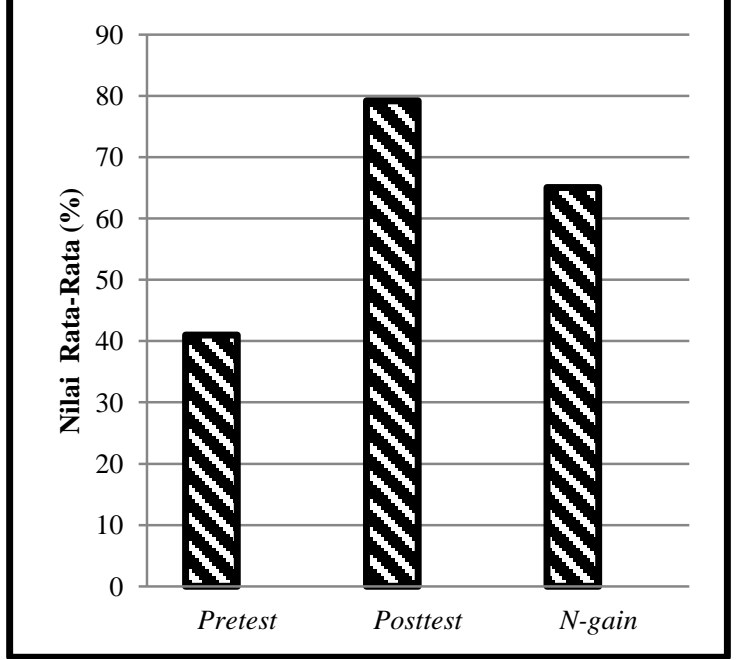

Gambar 2. Perbandingan nilai Rata-rata Pretest, Posttest, dan N-gain

Berdasarkan Gambar 1 diperoleh persentase nilai rata-rata pretest kelas IX-1 sebesar 41 dan posttest 79. Skor rata-rata N-gain sebesar 65 termasuk kategori sedang. Selanjutnya perbandingan $\mathrm{N}$-gain secara indivual peserta didik dapat dilihat pada Gambar 3.

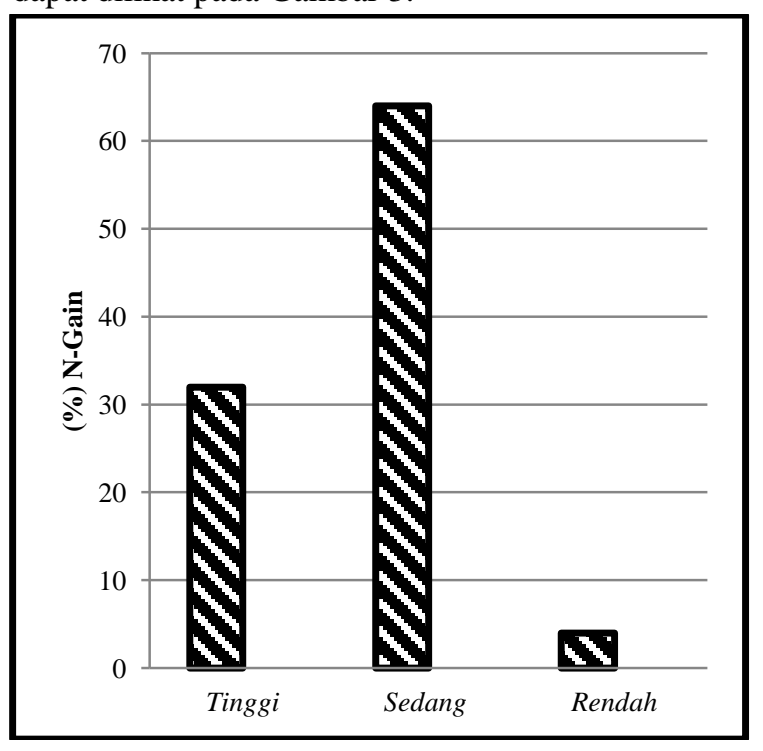

Gambar 3. Perbandingan Persentase N- gain Tiap Individual

Gambar 3 menunjukkan bahwa persentase gain yang dinormalisasi secara individu peserta didik kelas IX-1 termasuk kategori tinggi sebanyak 8 orang (32\%), kategori sedang sebanyak 16 orang ( $64 \%$ ) dan kategori rendah 1 orang (4\%). Selanjutnya dilakukan uji normalitas distribusi dan homogenitas pada materi listrik dinamis dilakukan dengan uji Lilifors (L) dengan aplikasi Ms.Excel 2010 dengan taraf signifikasi 0,05. Berdasarkan nilai pretest, posttest dan $\mathrm{N}$-gain diketahui bahwa data terdistribusi normal dan homogen. 
Selanjutnya, dilakukan uji-t dengan menggunakan independen Sampel Test.

Tabel 1 Hasil Uji Normalitas Skor tes Awal, Tes Akhir, dan Gain Penguasaan Konsep Listrik Dinamis

\begin{tabular}{|c|c|c|}
\hline \multicolumn{2}{|c|}{ Pre Test } & Post Tes \\
\hline L Maksimum & 0,35 & 0,60 \\
\hline L Tabel & 0,19 & 1,19 \\
\hline Distribusi Data & Normal & Normal \\
\hline
\end{tabular}

Tabel 2 Hasil Uji Homogenitas Skor Tes Awal dan tes Akhir Serta $N$-gain Penguasaan Konsep Listrik Dinamis

\begin{tabular}{|c|c|c|c|c|}
\hline $\begin{array}{c}\text { Homogenitas untuk } \\
\text { soal tes awal }\end{array}$ & $\begin{array}{c}\text { F } \\
\text { Hitung }\end{array}$ & dk & $\begin{array}{c}\text { F } \\
\text { Tabel }\end{array}$ \\
\cline { 1 - 4 } Tes Awal & Varian & $\mathbf{0 , 9 6}$ & 23 & $\mathbf{2 , 1 5}$ \\
\hline Ho & 1,55 & \multicolumn{4}{|c|}{ Terima } \\
\hline Kesimpulan & \multicolumn{4}{|c}{ Homogen } \\
\hline
\end{tabular}

\begin{tabular}{|c|c|c|c|c|}
\hline \multicolumn{2}{|c|}{$\begin{array}{c}\text { Homogenitas untuk } \\
\text { soal tes akhir }\end{array}$} & $\begin{array}{c}\text { F } \\
\text { Hitung }\end{array}$ & dk & $\begin{array}{c}\text { F } \\
\text { Tabel }\end{array}$ \\
\cline { 1 - 2 } Tes Akhir & Varian & & \multirow{2}{*}{$\mathbf{2 , 1 5}$} \\
\hline & 1,86 & 23 & 23 & \\
\hline & \multicolumn{4}{|c|}{ Terima } \\
\cline { 1 - 2 } Ho & \multicolumn{3}{|c|}{ Homogen } \\
\hline Kesimpulan & \multicolumn{3}{|c|}{} \\
\hline
\end{tabular}

\begin{tabular}{|c|c|c|c|c|}
\hline $\begin{array}{c}\text { Homogenitas untuk } \\
\text { gain }\end{array}$ & $\begin{array}{c}\text { F } \\
\text { Hitung }\end{array}$ & dk & $\begin{array}{c}\text { F } \\
\text { Tabel }\end{array}$ \\
\hline & Varian & & \\
\hline & 0,04 & 0,97 & 23 & \multirow{2}{*}{$\mathbf{2 , 1 5}$} \\
\hline & & & 23 & \\
\hline Ho & \multicolumn{4}{|c|}{ Terima } \\
\hline Kesimpulan & \multicolumn{3}{|c|}{ Homogen } \\
\hline
\end{tabular}

Tabel 3 Hasil Perhitungan Uji- t

\begin{tabular}{|c|c|c|c|}
\hline \multicolumn{5}{|c|}{ Data Hasil Penelitian } \\
\hline Data & Tes Awal & Tes Akhir & N-Gain \\
\hline N & 25 & 25 & 25 \\
\hline RATA2 & 26,18 & 66,22 & 0,56 \\
\hline STDEV & 1,24 & 1,36 & 0,19 \\
\hline MIN & 15 & 35 & 0,05 \\
\hline MAX & 35 & 75 & 0,60 \\
\hline VAR & 1,55 & 1,86 & 0,04 \\
\hline $\begin{array}{c}\text { \%RATA } \\
2\end{array}$ & 70 & 93 & 3 \\
\hline \multicolumn{5}{|c|}{ Uji t N-gain } \\
\hline t-hitung & 4,55 \\
\hline
\end{tabular}

\begin{tabular}{|c|c|c|c|}
\hline \multicolumn{3}{|c|}{ Data Hasil Penelitian } \\
\hline Data & Tes Awal & Tes Akhir & N-Gain \\
\hline \multicolumn{2}{|c|}{ t-tabel } & \multicolumn{2}{|c|}{2,02} \\
\hline \multicolumn{2}{|c|}{ Tolak } \\
\hline Ho & \multicolumn{2}{|c|}{ terdapat perbedaan } \\
\hline Kesimpulan & \multicolumn{2}{|c|}{} \\
\hline
\end{tabular}

Dari hasil perhitungan uji $\mathrm{t}$ pada tabel $4.5 \mathrm{di}$ atas Ho ditolak dengan interpretasi $-2,02<\mathrm{t}<2,02, \mathrm{t}$ hitung berada di luar daerah penerimaan Ho, maka hipotesis Ho ditolak karena $\mu_{1} \neq \mu_{2}$, Sehingga dapat disimpulkan terdapat perbedaan yang signifikan antara penguasan konsep listrik dinamis sebelum pembelajaran menggunakan modul praktikum berbasis pendekatan PACE dengan sesudah pembelajaran menggunakan modul praktikum berbasis pendekatan PACE.

Tabel 4.Nilai Tes motivasi belajar siswa kelas IX-1

\begin{tabular}{|l|l|c|c|}
\hline \multirow{2}{*}{ No } & \multirow{2}{*}{$\begin{array}{c}\text { Indikator } \\
\text { Motivasi Belajar }\end{array}$} & \multicolumn{2}{|c|}{ Nilai Rata-rata Kelas } \\
\cline { 3 - 4 } & Pretest & Postest \\
\hline 1 & Perhatian & 74,57 & 87,43 \\
\hline 2 & Ketertarikan & 68,53 & 90 \\
\hline 3 & Percaya Diri & 73,33 & 88,66 \\
\hline 4 & Kepuasaan & 70 & 88,66 \\
\hline
\end{tabular}

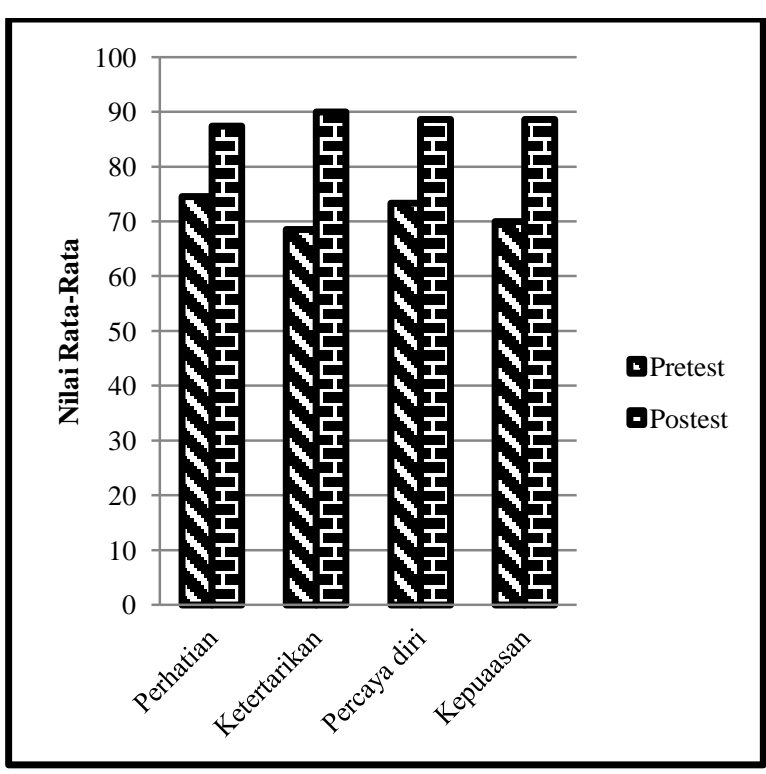

Gambar 4. Nilai Rata-rata Motivasi belajar siswa

Berdasarkan Tabel 4 dan Gambar 4 diperoleh tingkat motivasi belajar siswa pada materi listrik dinamis yang terdiri dari empat indikator mengalami peningkatan pada semua indikator.

Skor rata-rata berdasarkan urutan dari tinggi kerendah yaitu, 1)ketertarikan 2) kepuasaan 3) percaya diri 4) perhatian. Dengan hasil ini ketercapaian dari proses pembelajaran dapat 
diketahui dengan melihat hasil perubahan yang terjadi pada kemampuan siswa.

Analisis terhadap data observasi kegiatan pembelajaran dengan modul menunjukkan bahwa pembelajaran dengan modul pace dapat terlaksana dengan baik. Hal ini menunjukan bahwa modul praktikum berbasis pendekatan PACE mampu meningkatkan kepuasan terhadap usaha belajar siswa untuk mencapai hasil yang maksimal dalam materi listrik dinamis. Hal ini sesuai dengan hasil penelitian Srijaya (2012) melalui penelitiannya menunjukkan bahwa modul fisika kontekstual dapat meningkatkan hasil belajar peserta didik.

Dilihat dari motivasi yang muncul pada diri peserta didik juga didukung oleh sosial demografi orang tua, meliputi tingkatan pendidikan orang tua, pekerjaan dan penghasilan orang tua serta jarak tempat tinggal dengan sekolah sebagaimana dikemukakan oleh Rahimawati (2007) bahwa “ sosial demografi orang tua berpengaruh positif dan signifikan terhadap prestasi dan motivasi belajar". Dengan demikian, lingkungan, keluarga, sekolah dan peserta didik itu sendiri adalah hal penting yang sangat mempengaruhi perkembangan motivasi belajar seseorang. Tidak kalah pentingnya seorang guru harus mampu berperan sebagai motivator dalam proses pembelajaran sehingga proses pembelajaran menjadi lebih menarik dan berkesan bagi peserta didik dalam hal ini seorang guru harus mampu melakukan inovasi-inovasi baru pada proses pembelajaran yang memotivasi siswa untuk belajar lebih baik dan dapat meningkatkan prestasi belajarnya.

Selanjutnya peserta didik mampu menyelesaikan permasalahan yang ada dalam modul, dan menulis hasilnya kembali kedalam modul untuk dipresntasikan. Hal ini sesuai dengan hasil penelitian Alimah (2012) kualitas modul yang dikembangkan berkategori baik, dan layak digunakan dalam pembelajaran Fisika. Selain itu peserta didik merasa memiliki kemauan yang tinggi untuk mengikuti pelajaran, media yang digunakan juga tidak membosankan dan mudah digunakan sehingga membuat mereka semakin tertarik untuk belajar. Hal ini sesuai dengan hasil penelitian yang dilakukan oleh Gusti dan Wayan (2013) pengembangan modul IPA dapat meningkatkan motivasi siswa belajar dimana siswa terlihat aktif dan antusias dalam belajar sehingga menumbuhkan inovasi dalam mengelola pembelajaran.

Dengan demikian diperoleh kesimpulan bahwa terjadi peningkatan dari kempat indikator tersebut,baik pada indikator perhatian, kepuasaan, percaya diri dan ketertarikan siswa yang ditunjukan dari peningkatan setiap indikator yang ada. Hal ini menunjukkan bahwa siswa bersungguh-sungguh untuk belajar sehingga memudahkan mereka dalam memahami materi yang dipelajari. Pemanfaatan modul fisika kontektual dapat membantu siswa lebih memahami materi pembelajaran dan meningkatkan pemahaman konsep, Sujanem (2012). Selain motivasi observasi terhadap pendekatan PACE juga dilakukan, yang mana pada tiap tahapan yang dilakukan yaitu tahap perencanaan, aktivitas, diskusi kelas dan latihan mengalami peningkatan kearah yang lebih baik. hal ini menunjukkan bahwa terdapat perbedaan yang signifikan antara pembelajaran yang dilakukan sebelum dan sesudah menggunakan modul. Faizi (2013) mengatakan bahwa penggunaan media dalam pembelajaran dapat menambah motivasi belajar siswa sehingga perhatian peserta didik terhadap materi pembelajaran dapat lebih meningkat. Peningkatan motivasi belajar siswa dapat disebabkan oleh adanya perbedaan kegiatan pembelajaran yang diterima oleh siswa dalam kelas, Sesuai dengan paparan Rohani (2004) salah satu hal yang bisa dilakukan oleh guru dalam pembelajaran untuk dapat meningkatkan motivasi berupa mewujudkan suasana kelas yang menggembirakan dan menyenangkan akan mendorong partisipasi siswa untuk terlibat dalam pembelajaran.

\section{PENUTUP}

\section{A. Simpulan}

Hasil ini menunjukkan peningkatan motivasi belajar siswa kelas IX-1 SMP Negeri 10 Takengon pada pembelajaran materi listrik dinamis melalui modul dengan pendekatan PACE dan mengalami peningkatan yang signifikan, disamping tanggapan yang diberikan guru dan siswa juga positif setelah memperoleh pembelajaran modul PACE pada materi listrik dinamis.

\section{B. Saran}

Modul yang dikembangan dalam penelitian ini telah diimplementasikan pada satu sekolah, agar bisa diterapkan secara menyeluruh peneliti menyarankan untuk diterapkan di sekolah lain.

\section{DAFTAR PUSTAKA}

Alimah, L.F. 2012. Pengembangan Modul Fisika pada Pokok Bahasan Listrik Dinamis Berbasis Domain Pengetahuan Sains untuk Mengoptimalkan Minds-On Siswa SMA Negeri 2 Purworejo Kelas X Tahun Pelajaran 2012/2013. Radiasi. 3(1): (19-23). 
Creswell, John W. 2013. Research Design. Yogyakarta: PustakaPelajar.

Depdiknas. (2006). Kurikulum Tingkat Satuan Pendidkan Sekolah Menengah Pertama, Jakarta.

Gusti dan Wayan. 2013. Pengembangan Modul IPA Dengan Pendekatan Kontekstual Untuk Kelas V SD Negeri 2 Semarapura Tengah. E-Journal Program Pascasarjana Universitas Pendidikan Ganesha. Vol 3:1-10.

Faizi, M. 2013. Ragam Metode Mengajarkan Eksakta pada Murid. Yokyakarta: Diva Press.

Furqan, 2015 Penegembngan Modul Praktikum Berbasis Inkuiri Untuk Meningkatkan Ketrampilan Proses Sains dan Motivasi Belajar Siswa X di SMA N 1 Bukit Bener Meriah. Tesis Program Pascasarjana Universitas Pendidikan Unsyiah

Kamphen, P,Cdkk. 2003. Teaching A Single Physics Module Through Based Learning in Lecture-Based Curriculum. American Journal of Phisics, (Online), 72: 829, (http://dx.doi.org/10.1119/1.1645280.,diakse s 23 Januari 2015).

Kaniawati, I. 2010. Pengembangan Model Pembelajaran Fisika Berbasis Fenomena untuk Meningkatkan Pemahaman Konsep, Keterampilan Proses Sains, dan Berpikir Tingkat Tinggi Pembelajar.UPI. Bandung

Lawson, R.J 2011. Constructively Aligned Teaching methods and Student Approaches To Learning And Motivation Orientation Global. Journal of Human Social Science, V.11.Issue 8 .

Liliasari. 2000. Model Pembelajaran IPA untuk Meningkatkan Ketrampilan Berpikir Tingkat Tinggi Calon Guru sebagai Kecenderungan baru pada Era Globalisasi. Jurnal Pengajaran MIPA. 2(1).

Nursisto. 2002. Peningkatan Prestasi Sekolah Menengah. Jakarta: Penerbit Insan Cendekia

Rahimawati, 2007, Pengaruh Sosial Demografi Orang Tua Terhadap Prestasi Belajar Siswa SMA Negeri I Takengon Kabupaten Aceh Tengah, Pustaka: Magister Manajemen Unsyiah.

Rohani, A. 2004, Pengelolaan Pengajaran Edisi Revisi. Jakarta: Rineke Cipta.

Sardiman, A.M. 2006. Interaksi dan Motivasi Belajar Mengajar. Jakarta: Grafindo

Setyaningrum, Rus, dkk. 2013. Efektivitas Pelaksanaan Praktikum Fisika Siswa SMA
Negeri Kabupaten Purworejo. Jurnal Radiasi 3: 83-86.

Srijaya, S. P. 2012. Pengembangan Modul Fisika Kontekstual Untuk Meningkatkan Hasil Belajar Fisika Peserta Didik Kelas X Semester 2 Di SMK Negeri 3 Singaraja. Tesis tidak dipublikasi. Program Studi Teknologi Pembelajaran . Program Pascasarjana Undiksha.

Sujanem.2012. Pengembanagn Modul Fisika Kontekstual Interaktif Berbasis Web Untuk Meningkatkan Pemahan Konsep Dan Hasil Belajar Pada SMA di Singaraja. Jurnal Nasional Pendidikan teknik informatika. 1(2):(103-117).

Suparno, P. 2010. Metode Penelitian Pendidikan Fisika, Yogyakarta: Universitas Sanata Dharma.

Susilo, H. 2004. Pembelajaran Kontekstual Untuk Peningkatan Pemahaman Peserta didik. Makalah disampaikan pada Kegiatan Peningkatan Pembelajaran di SMU LAB UM tanggal 16 Januari 2004.

Wahyudin, Sutikno, dan Isa A. 2009. Keefektifan Pembelajaran Menggunakan Metode Inkuiri Terbimbing untuk Meningkatkan Minatdan Pemahaman Siswa. Jurnal Pendidikan Fisika Indonesia, (Online), 6(2010):58-62, (http:// journal.unnes.ac.id/ diakses 5 Februari 2015). 